\title{
Glacial changes in the Gangdisê Mountains from 1970 to 2016
}

\author{
LIU Juan ${ }^{1}$, 'YAO Xiaojun ${ }^{1}$, LIU Shiyin ${ }^{2,3}$, GUO Wanqin², XU Junli ${ }^{4}$
}

1. College of Geography and Environmental Science, Northwest Normal University, Lanzhou 730070, China;

2. State Key Laboratory of Cryosphere Sciences, Northwest Institute of Eco-Environment and Resources, CAS, Lanzhou 730000, China;

3. Institute of International Rivers and Eco-Security, Yunnan University, Kunming 650091, China;

4. Yancheng Teachers University, Yancheng 224051, Jiangsu, China

\begin{abstract}
Based on the revised First Chinese Glacier Inventory (FCGI), the Second Chinese Glacier Inventory (SCGI) and Landsat OLI images for 2015-2016, we analyzed the spatial-temporal variation characteristics of glaciers in the Gangdisê Mountains from 1970 to 2016. The results showed that there were 3953 glaciers with a total area of $1306.45 \mathrm{~km}^{2}$ and ice volume of $\sim 58.16 \mathrm{~km}^{3}$ in the Gangdisê Mountains in 2015-2016. Glaciers with sizes of $0.1-5 \mathrm{~km}^{2}$ and $<0.5 \mathrm{~km}^{2}$ accounted for the largest area and the most amounts of glaciers in the Gangdisê Mountains, respectively. Over the past five decades, the area of glaciers in the Gangdisê Mountains decreased by $854.05 \mathrm{~km}^{2}\left(-1.09 \% \cdot \mathrm{a}^{-1}\right)$, accounting for $39.53 \%$ of the total glacier area in 1970. The increase in temperature during the ablation period was the most important cause for glacier retreat. Compared to other mountains in western China, the Gangdisê Mountains have experienced the strongest glacial retreat, and the rate of recession has increased in recent years. The decrease of glacier area was mainly concentrated at elevations of 5600-6100 m, and no change in glacier area was observed at elevations above $6500 \mathrm{~m}$. The number and area of glaciers decreased in all orientations in the Gangdisê Mountains except for south- and southeast-oriented glaciers. Among them, north-oriented glaciers suffered the largest loss of glacier area, while glacier retreat saw the fastest in northwest-oriented glaciers. The rate of glacier retreat increased from west to east in the Gangdisê Mountains. The relative rate of glacier area change was the highest in the eastern section of the Gangdisê Mountains $\left(-1.72 \% \cdot a^{-1}\right)$, followed by the middle section $\left(-1.67 \% \cdot a^{-1}\right)$ and the western section $\left(-0.83 \% \cdot a^{-1}\right)$.
\end{abstract}

Keywords: glacier change; glacier inventory; climate change; Gangdisê Mountains

Received: 2019-02-19 Accepted: 2019-05-30

Foundation: National Natural Science Foundation of China, No.41561016, No.41861013, No.41801052; National Basic Work Program of MST, No.2013FY111400; Youth Scholar Scientific Capability Promoting Project of Northwest Normal University, No.NWNU-LKQN-14-4

Author: Liu Juan (1993-), Master Candidate, specializing in the environmental science and geographic information system. E-mail: liujuan_qx@163.com

*Corresponding author: Yao Xiaojun, Professor, E-mail: yaoxj_nwnu@163.com 


\section{Introduction}

Glaciers are important components of the cryosphere (Kargel et al., 2014). As solid fresh-water resources, glaciers play critical roles in socio-economic development, ecosystems and the environment maintenance in mountainous areas (Shi, 2001; Zhang et al., 2012). Glaciers act as sensitive indicators of climate change, which are closely related to climate change (Oerlemans, 1994). Under the background of global warming, continuous glacier retreat not only has important effects on water resources and sea level rise (Immerzeel et al., 2010; Church et al., 2013), but also contributes to glacial lake outburst floods, debris flows, and other disaster events (Benn et al., 2012; Wang et al., 2015). Therefore, the relationship between glacier mass balance and climate change along with the utilization of water sources in the cryosphere and the associated disaster risk have become an important research hotspot (Wu et al., 2018).

Due to its large area of well-developed modern and Quaternary glaciers, the Tibetan Plateau was known as the third pole of the world (Qiu, 2008). The glaciers in this region were mainly distributed in the Kunlun Mountains, Himalayas, Karakoram, Qilian Mountains, Tanggula Mountains, Pamir Plateau and Nyainqetanglha Range (You et al., 2013). Since the 20th century, glaciers on the Tibetan Plateau have been obviously receded, and this trend has intensified in recent years (Pu et al., 2004). The retreat of glaciers on the Tibetan Plateau not only changed the surface environment of the plateau, but also directly affected the water supply of billions of people and altered the atmospheric circulation over half the planet (Qiu, 2008). At present, research on glacial changes in the Tibetan Plateau is primarily focused on the Himalayas (Li et al., 2011; Ye et al., 2007), the Kangri Karoo Mountains (Wu et al., 2018; Liu et al., 2005), the western Nyainqetanglha Range (Shangguan et al., 2008; Kang et al., 2007), the Tanggula Mountains (Wang et al., 2016), and Karakoram (Gardelle et al., 2012; Kääb et al., 2015; Gardelle et al., 2013). These studies indicated that glacial retreat in the Tibetan Plateau differed greatly by region, with the extent of retreat decreasing gradually from the Himalayas to the continental interior (Yao et al., 2012). This means that glaciers in the marginal mountainous area of the Tibetan Plateau are more sensitive to climate change than those in the hinterland (Liu et al., 2006; Yao et al., 2012). The Gangdisê Mountains are part of the boundary between the monsoon and non-monsoon regions in China along with the important geographic boundary between the northern and southern Tibetan Plateau. Thus, it is of great significance to recognize glacier changes and the responses of glaciers to climate change in the Gangdisê Mountains. Based on the revised First and Second Chinese Glacier Inventory and Landsat OLI images during 2015-2016, we analyzed the spatial-temporal variation characteristics of glaciers in the Gangdisê Mountains for the past half-century. The results of this study would supplement the basic data on glacial changes in the Gangdisê Mountains and provide a scientific basis for the rational use of water resources in this region.

\section{Study area}

The Gangdisê Mountains $\left(29^{\circ} 14^{\prime}-33^{\circ} 42^{\prime} \mathrm{N}, 78^{\circ} 52^{\prime}-90^{\circ} 03^{\prime} \mathrm{E}\right)$ extend across the southeastern part of the Tibet Autonomous Region (Figure 1). Starting at Sassel Ridge in the southeastern part of the Karakoram in the west and ending at the southwest part of the Nam Co in the east, 
the Gangdisê Mountains connect to the western part of the Nyainqetanglha Range. The Gangdisê Mountains are roughly parallel to the Himalayas and have a NW-SE trend. The Gangdise Mountains are one of the most striking tectonic units in the southern margin of the Tibetan Plateau and Eurasia (Xu and Ding, 2015). The Gangdisê Mountains extend approximately $1600 \mathrm{~km}$ from west to east, with an average width of about $100 \mathrm{~km}$. The main peak in the Gangdisê Mountains is Gangrinboqê, while Mount Luobo (also known as Lombo Kamgri, $7095 \mathrm{~m}$ ) is the highest peak. In addition to being an important north-south geographical boundary of the Tibetan Plateau, the Gangdisê Mountains are also an important ridge between the exterior and interior systems of the plateau.

While the modern glaciers in the Gangdisê Mountains are small and mainly concentrated in the alpine areas, the ancient glaciers are huge (Li et al., 1986). The glacier types in the Gangdisê Mountains include polar glaciers in the western part and continental glaciers in the eastern part (Shi and Liu, 2000). Glaciers in this region are dominated by cirque glaciers and hang glaciers, with few valley glaciers (Li et al., 1986). In the SCGI dataset, glaciers in the Gangdisê Mountains are categorized into the following regions: the Ganges River basin (5O), Indus River basin (5Q), and Tibetan Plateau interior area (5Z) (Shi, 2005). The Ganges River basin includes the Yarlung Zangbo River basin (5O2); the Indus River basin includes the Sênggê Zangbo basin (5Q1) and Langqên Zangbo basin (5Q2); and the Tibetan Plateau interior area includes the Selin Co basin (5Z2), Zhari Namco basin (5Z3), and Bangong Co basin (5Z4).

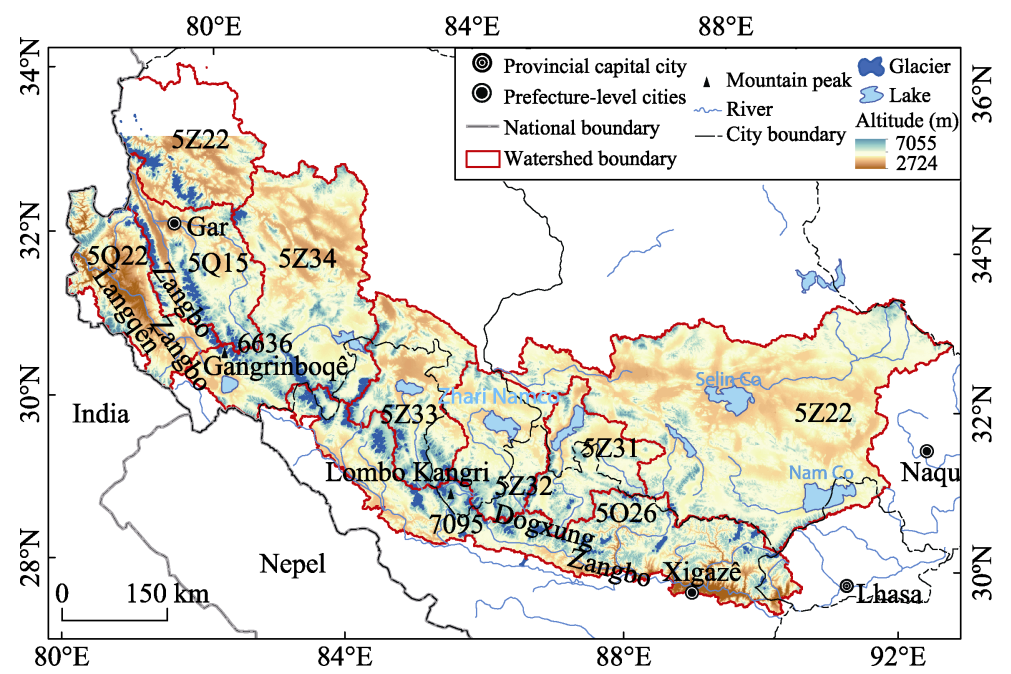

Figure 1 Distribution of glaciers in the Gangdisê Mountains

\section{Data and methods}

\subsection{Data}

The data sources for the FCGI dataset of the Gangdisê Mountains were topographic maps based on aerial photogrammetry from 1970 to 1980 (33 topographic maps at a scale of 1:50,000 and 56 maps at a scale of 1:100,000). These topographic maps were concentrated in three periods: 1970-1972, 1974, and 1980. The number of topographic maps correspond- 
ing to 1970 accounted for more than half of the total number of maps. In the FCGI dataset, the glacier area in this period accounts for $65.67 \%$ of the total area. Therefore, this study used the FCGI data for 1970. The data sources for the SCGI dataset were 20 Landsat $\mathrm{TM} / \mathrm{ETM}+$ remote sensing images with little cloud or snow cover. The data sources of the 2015-2016 glacier dataset were 13 Landsat OLI remote sensing images (11 were collected in 2016 and 2 in 2015; Table 1).

Table 1 Landsat OLI images used to obtain glacier data in the Gangdisê Mountains from 2015-2016

\begin{tabular}{|c|c|c|c|c|c|c|c|}
\hline \multirow{2}{*}{ Number } & \multicolumn{2}{|c|}{ Orbit number } & \multirow{2}{*}{ Acquisition date } & \multirow{2}{*}{ Number } & \multicolumn{2}{|c|}{ Orbit number } & \multirow{2}{*}{ Acquisition date } \\
\hline & Path & Row & & & Path & Row & \\
\hline 1 & 138 & 39 & 2016-04-27 & 8 & 143 & 38 & 2016-10-07 \\
\hline 2 & 138 & 40 & 2016-04-27 & 9 & 143 & 39 & 2016-09-05 \\
\hline 3 & 139 & 39 & 2016-03-17 & 10 & 144 & 38 & 2016-06-24 \\
\hline 4 & 140 & 39 & 2016-10-18 & 11 & 145 & 37 & 2016-10-15 \\
\hline 5 & 141 & 39 & 2016-05-18 & 12 & 145 & 38 & 2016-09-03 \\
\hline 6 & 141 & 40 & 2015-10-07 & 13 & 146 & 37 & 2016-09-10 \\
\hline 7 & 142 & 39 & $2015-09-28$ & & & & \\
\hline
\end{tabular}

The digital elevation model (DEM) data used in the FCGI and SCGI datasets in the Gangdisê Mountains were topographic maps and SRTM V4.1 data, respectively (Liu et al., 2015). The DEM data used in the 2015-2016 glacier dataset were ASTER GDEM data with a spatial resolution of $30 \mathrm{~m}$. The annual temperature and precipitation data for the Gangdisê Mountains from 1970-2016 were extracted from the $0.5^{\circ} \times 0.5^{\circ}$ gridded dataset of monthly temperature and precipitation in China, which was provided by the China Meteorological Data Service Center (http://data.cma.cn).

\subsection{Methods}

Studies have shown that the FCGI dataset contains some errors, such as incorrect boundary mapping of glaciers, small glaciers being missed, and seasonal snow spots being wrongly interpreted as glaciers (Liu et al., 2005). To improve the quality of the dataset, the FCGI glacier data were cross-validated with the SCGI data for the Gangdisê Mountains. Glaciers with large differences in shape, disappeared glaciers (i.e., glaciers exiting only in the FCGI dataset), and new glaciers (i.e., glaciers exiting only in the SCGI dataset) were examined, and the shapes of these glaciers were manually revised. The revision of the FCGI dataset in the Gangdisê Mountains was based on topographic maps at scales of 1:50,000 and 1:100,000, and glacier boundaries were revised by manual digitization. The data sources used in the SCGI dataset were three Landsat TM remote sensing images with little cloud or snow cover in 2009; the method of the SCGI was adopted to revise the glacier boundary. Moreover, the collection and processing of the glacier dataset for the Gangdisê Mountains from 2015-2016 were also carried out using the SCGI dataset method (Guo et al., 2015).

The accuracy of glacier boundary extraction is mainly affected by the sensor and image registration errors (Hall et al., 2003; Williams et al., 1997). Remote sensing interpretations of glacier boundary can be verified by field investigation or comparison with high-resolution remote sensing images (Shangguan, 2007). In this study, the errors resulting from the spatial 
resolutions of satellite remote sensing images were calculated with the following formula:

$$
\varepsilon=N \times A
$$

where $\varepsilon$ is the error $\left(\mathrm{km}^{2}\right) ; N$ is the perimeter of the glacier boundary; and $A$ is the length of half a pixel (which are $15 \mathrm{~m}$ for Landsat TM/ETM+/OLI images). The calculated errors in glacier area in the SCGI and 2016 glacier datasets for the Gangdisê Mountains resulting from image spatial resolution were $\pm 122.97 \mathrm{~km}^{2}( \pm 8.29 \%)$ and $\pm 116.89 \mathrm{~km}^{2}( \pm 8.95 \%)$, respectively.

Glacier ice volume is an important indicator of global sea level rise (Liu et al., 2006). At present, the empirical volume-area formula is typically used to calculate ice volume (Gärtner-Roer et al., 2014):

$$
V=c \times A^{\gamma}
$$

where $V\left(\mathrm{~km}^{3}\right)$ is the ice volume of a glacier with surface area $A\left(\mathrm{~km}^{2}\right)$; and $c$ and $\gamma$ are empirical coefficients. In this study, the glacier ice volume in the Gangdisê Mountains was calculated by the numerical methods proposed by Radić and Hock (2010), Grinsted (2013), and Liu et al. (2003), and the average values obtained from the above three methods were determined (Liu et al., 2015).

\section{Results}

\subsection{The contemporary glaciers in the Gangdisê Mountains}

4.1.1 General glacier characteristics in the Gangdisê Mountains

In 2015-2016, there were 3953 glaciers with a total area of $1306.45 \mathrm{~km}^{2}$ and ice volume of $58.16 \mathrm{~km}^{3}$ in the Gangdisê Mountains. As shown in Figure 2, glaciers with sizes of 0.1-5 $\mathrm{km}^{2}$ accounted for the largest number of glaciers in the Gangdisê Mountains, while glaciers with sizes $<0.5 \mathrm{~km}^{2}$ accounted for the largest glacierized area. Specifically, 3375 glaciers had areas $<0.5 \mathrm{~km}^{2}$, accounting for $85.38 \%$ of all glaciers in the Gangdisê Mountains. Thus, the Gangdisê Mountains are dominated by small glaciers. This can be attributed to the high snowline (5800-6000 m), steep mountain body, and fragmented topography of the Gangdisê Mountains, which hinder the development of large glaciers. The number of glaciers decreased rapidly as glacier size increased, and only one glacier with an area $>20 \mathrm{~km}^{2}$ (GLIMS coded as G083478E31014N, area of $21.14 \mathrm{~km}^{2}$ ) was present. Glaciers with sizes in the range of $0.1-5 \mathrm{~km}^{2}$ totaled an area of $1067.85 \mathrm{~km}^{2}$ accounting for $81.74 \%$ of the total area of glaciers in the Gangdisê Mountains. Although glaciers with sizes $<0.1 \mathrm{~km}^{2}$ were numerous, their total area was only $79.34 \mathrm{~km}^{2}(6.07 \%$ of the total glacierized area).

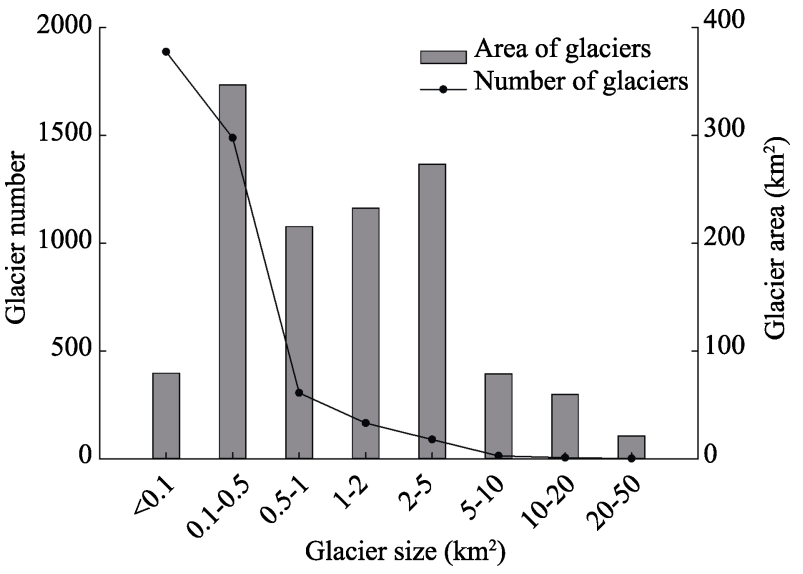

Figure 2 Number and area of glaciers with different sizes in the Gangdisê Mountains from 2015-2016 
4.1.2 Distributions of glaciers in different drainage systems

As described in Section 2, glaciers in the Gangdisê Mountains were assigned to three drainage basins: 5O, 5Q, and 5Z. Table 2 lists the statistics of glaciers in these drainage systems. Clearly, most glaciers were located in the Tibetan Plateau interior, which had the greatest glacier area, number, and ice volume, followed by the Ganges River basin and Indus River basin. Although the number of glaciers in the Ganges River basin and Indus River basin on the southern slope of the Gangdisê Mountains (2302 glaciers, accounting for $58.22 \%$ of all glaciers) was larger than that on the northern slope of the Tibetan Plateau interior area, the glacier area was slightly smaller $\left(626.10 \mathrm{~km}^{2}\right.$, accounting for $47.92 \%$ of the total glacier area). Among tertiary basins, the area and number of glaciers were the largest in Dogxung Zangbo basin. The Selin Co basin contained the least glacier resources in the Gangdisê Mountains (43 glaciers with an area of $15.46 \mathrm{~km}^{2}$ ). In the Zhari Namco basin, the area and number of glaciers were the 2nd and 3rd largest in the Gangdisê Mountains; however, the average glacier area and ice volume were the largest in this basin $\left(0.65 \mathrm{~km}^{2}\right.$ and $19.47 \mathrm{~km}^{3}$, respectively). Although the Bangong Co basin contained many glaciers, the average glacier size was only $0.15 \mathrm{~km}^{2}$, the smallest in the Gangdisê Mountains.

Table 2 Glacier statistics for different basins in the Gangdisê Mountains from 2015-2016

\begin{tabular}{|c|c|c|c|c|c|c|c|c|}
\hline \multirow{2}{*}{ Basin (code) } & \multirow{2}{*}{$\begin{array}{l}\text { Secondary basin } \\
\text { (code) }\end{array}$} & \multirow{2}{*}{$\begin{array}{l}\text { Tertiary basin } \\
\quad \text { (code) }\end{array}$} & \multicolumn{2}{|c|}{ Number } & \multicolumn{2}{|c|}{ Area } & \multicolumn{2}{|c|}{ Volume } \\
\hline & & & & $(\%)$ & $\left(\mathrm{km}^{2}\right)$ & $(\%)$ & $\left(\mathrm{km}^{2}\right)$ & $(\%)$ \\
\hline $\begin{array}{l}\text { Ganges } \\
\text { River }(5 \mathrm{O})\end{array}$ & $\begin{array}{l}\text { Yarlung Zangbo } \\
\text { River (5O2) }\end{array}$ & $\begin{array}{l}\text { Dogxung Zangbo } \\
(5 \mathrm{O} 26)\end{array}$ & 1372 & 34.71 & 413.65 & 31.66 & 16.63 & 28.65 \\
\hline \multirow{3}{*}{$\begin{array}{l}\text { Indus River } \\
(5 \mathrm{Q})\end{array}$} & $\begin{array}{l}\text { Sênggê Zangbo } \\
(5 \mathrm{Q} 1)\end{array}$ & $\begin{array}{l}\text { Sênggê Zangbo } \\
\text { (5Q15) }\end{array}$ & 703 & 17.78 & 172.36 & 13.19 & 7.54 & 12.99 \\
\hline & $\begin{array}{l}\text { Langqên Zangbo } \\
\text { (5Q2) }\end{array}$ & $\begin{array}{l}\text { Langqên Zangbo } \\
\text { (5Q22) }\end{array}$ & 227 & 5.74 & 40.09 & 3.07 & 1.30 & 2.24 \\
\hline & & Total & 930 & 23.52 & 212.45 & 16.26 & 8.84 & 15.23 \\
\hline \multirow{7}{*}{$\begin{array}{l}\text { Tibetan } \\
\text { Plateau } \\
\text { interior } \\
(5 Z)\end{array}$} & Selin Co (5Z2) & Selin Co (5Z22) & 43 & 1.09 & 15.46 & 1.18 & 0.66 & 1.14 \\
\hline & & Dangta Yumco (5Z31) & 104 & 2.63 & 27.28 & 2.09 & 0.93 & 1.60 \\
\hline & \multirow[b]{2}{*}{ Zhari Namco (5Z3) } & Zhari Namco (5Z32) & 182 & 4.61 & 61.48 & 4.71 & 2.52 & 4.34 \\
\hline & & Taro Co $(5 Z 33)$ & 301 & 7.61 & 157.64 & 12.07 & 6.80 & 11.71 \\
\hline & \multirow{3}{*}{ Bangong Co (5Z4) } & $\begin{array}{l}\text { Ngangla Ring } \\
\text { Co }(5 Z 34)\end{array}$ & 531 & 13.43 & 343.12 & 26.26 & 19.47 & 33.54 \\
\hline & & Bangong Co (5Z42) & 490 & 12.40 & 75.37 & 5.77 & 2.20 & 3.79 \\
\hline & & Total & 1651 & 41.78 & 680.35 & 52.08 & 29.72 & 51.19 \\
\hline
\end{tabular}

4.1.3 Distributions of glaciers in different administrative divisions

In terms of administrative divisions, glaciers in the Gangdisê Mountains were located within the cities (regions) of Lhasa, Xigazê, Ngari and Naqu in the Tibet Autonomous Region(Table 3). Among these regions, Ngari contained the largest glacier number, area, and ice volume, followed by Xigazê. The glacier numbers, areas and ice volumes in Ngari and Xigazê accounted for $97.72 \%, 97.44 \%$, and $97.47 \%$ of the corresponding totals in the Gangdisê Mountains, respectively. The total number of glaciers in Lhasa and Naqu accounted for only $2.28 \%$ of glaciers in the Gangdisê Mountains, and the area and ice volume of glaciers in these regions accounted for only $2.56 \%$ and $2.52 \%$ of the corresponding totals, respectively. 
While the number and area of glaciers in Lhasa were small, this region had the largest average glacier size $\left(0.50 \mathrm{~km}^{2}\right)$.

Table 3 Glacier statistics in different administrative divisions in the Gangdisê Mountains from 2015-2016

\begin{tabular}{|c|c|c|c|c|c|c|}
\hline \multirow{2}{*}{ City (region) } & \multicolumn{2}{|c|}{ Number } & \multicolumn{2}{|c|}{ Area } & \multicolumn{2}{|c|}{ Volume } \\
\hline & & $(\%)$ & $\left(\mathrm{km}^{2}\right)$ & $(\%)$ & $\left(\mathrm{km}^{3}\right)$ & $(\%)$ \\
\hline Lhasa & 46 & 1.17 & 22.83 & 1.75 & 1.13 & 1.94 \\
\hline Xigazê & 1603 & 40.55 & 607.87 & 46.53 & 27.09 & 46.58 \\
\hline Ngari & 2260 & 57.17 & 665.13 & 50.91 & 29.60 & 50.89 \\
\hline $\mathrm{Naqu}$ & 44 & 1.11 & 10.62 & 0.81 & 0.34 & 0.58 \\
\hline
\end{tabular}

\subsection{Glacier changes in the Gangdisê Mountains from 1970 to 2016}

4.2.1 Changes of glacier number, area and ice volume

When checking the FCGI dataset of the Gangdisê Mountains, there were 436 glaciers (with an area of $244.97 \mathrm{~km}^{2}$ ), that were not in the original FCGI dataset accounting for $11.34 \%$ of the total area. After revision, there were 4654 glaciers in the Gangdisê Mountains with a total area of $2160.50 \mathrm{~km}^{2}$ (average area of $0.46 \mathrm{~km}^{2}$ and ice volume of $96.06 \mathrm{~km}^{3}$ ). In the revised SCGI dataset for the Gangdisê Mountains, there were 4207 glaciers with a total area of $1483.28 \mathrm{~km}^{2}$ (average area of $0.35 \mathrm{~km}^{2}$ and ice volume of $66.01 \mathrm{~km}^{3}$ ). Thus, 313 glaciers with an area of $187.01 \mathrm{~km}^{2}$ were not contained in the original SCGI dataset.

The statistics from the FCGI and SCGI datasets indicated that the glacial area in the Gangdisê Mountains decreased by $677.22 \mathrm{~km}^{2}(-31.35 \%)$ from 1970 to 2009 . The relative rate of glacier area change was $0.96 \% \cdot \mathrm{a}^{-1}$, and the loss of ice volume was $30.05 \mathrm{~km}^{3}(-0.77$ $\left.\mathrm{km}^{3} / \mathrm{a}\right)$. In total, 914 glaciers with a total area of $106.52 \mathrm{~km}^{2}$ disappeared completely. An additional 171 glaciers decreased in area from $142.26 \mathrm{~km}^{2}$ to $80.99 \mathrm{~km}^{2}$ and split into 375 smaller glaciers. From 2009 to 2016, the number of glaciers in the Gangdisê Mountains decreased by $254(-6.04 \%)$, with 298 glaciers (with an area of $11.93 \mathrm{~km}^{2}$ ) disappeared completely; an additional 25 glaciers split into 53 smaller glaciers and decreased in area from $8.08 \mathrm{~km}^{2}$ to $4.81 \mathrm{~km}^{2}$. In the past seven years, the area of glaciers in the Gangdisê Mountains decreased by $176.83 \mathrm{~km}^{2}(-11.92 \%)$, the relative rate of glacier area change was $1.78 \% \cdot \mathrm{a}^{-1}$, and the loss of ice volume was $7.85 \mathrm{~km}^{3}\left(-1.12 \mathrm{~km}^{3} / \mathrm{a}\right)$. The number of glaciers in the Gangdisê Mountains decreased by $701(-15.06 \%)$, the glacier area decreased by $854.05 \mathrm{~km}^{2}$ $(-39.53 \%)$, the relative rate of glacier area change was $1.09 \% \cdot \mathrm{a}^{-1}$, and the loss of ice volume was approximately $37.90 \mathrm{~km}^{3}$. The loss rates were $-0.82 \mathrm{~km}^{3} / \mathrm{a}$ and $-0.86 \% \cdot \mathrm{a}^{-1}$. Obviously, the number, area, and ice volume of glaciers in the Gangdisê Mountains decreased from 1970 to 2009 and from 2009 to 2016; however, the extents of the decreases in glacier area and ice volume were greater from 2009-2016 compared to those from 1970-2016.

As shown in Figure 3, the number and area of glaciers with sizes $<0.1 \mathrm{~km}^{2}$ increased in the Gangdisê Mountains from 1970 to 2016, while the number and area of glaciers with other sizes decreased. Among glaciers of different sizes, the area of glaciers with sizes of $0.1-0.5 \mathrm{~km}^{2}$ decreased the most $\left(-255.8 \mathrm{~km}^{2}\right)$, followed by glaciers with sizes of $0.5-1 \mathrm{~km}^{2}$ $\left(-181.05 \mathrm{~km}^{2}\right)$. The decrease in the numbers of glaciers in these two sizes range led directly to the increases in the number and area of glaciers with sizes $<0.1 \mathrm{~km}^{2}\left(812\right.$ and $\left.11.31 \mathrm{~km}^{2}\right)$. 
The decreases in glacier area for glaciers with sizes of $1-2 \mathrm{~km}^{2}, 2-5 \mathrm{~km}^{2}$, and $5-10 \mathrm{~km}^{2}$ ranged from $-163.40 \mathrm{~km}^{2}$ to $-121.53 \mathrm{~km}^{2}$. The numbers of glaciers with sizes of $10-20 \mathrm{~km}^{2}$ and $20-50 \mathrm{~km}^{2}$ remained unchanged from 1970 to 2016 , and glaciers with sizes of $20-50 \mathrm{~km}^{2}$ experienced the smallest decrease in area $\left(-2.06 \mathrm{~km}^{2}\right)$ among all glacier size groups. The relative rate of glacier area change was calculated for glaciers with different sizes, indicated that the retreat rate with decreasing glacier size. Specifically, small glaciers $\left(<0.1 \mathrm{~km}^{2}\right)$ retreated the fastest $\left(-3.88 \% \cdot \mathrm{a}^{-1}\right)$ followed by glaciers with an area of $0.1-0.5 \mathrm{~km}^{2}\left(-2.03 \% \cdot \mathrm{a}^{-1}\right)$

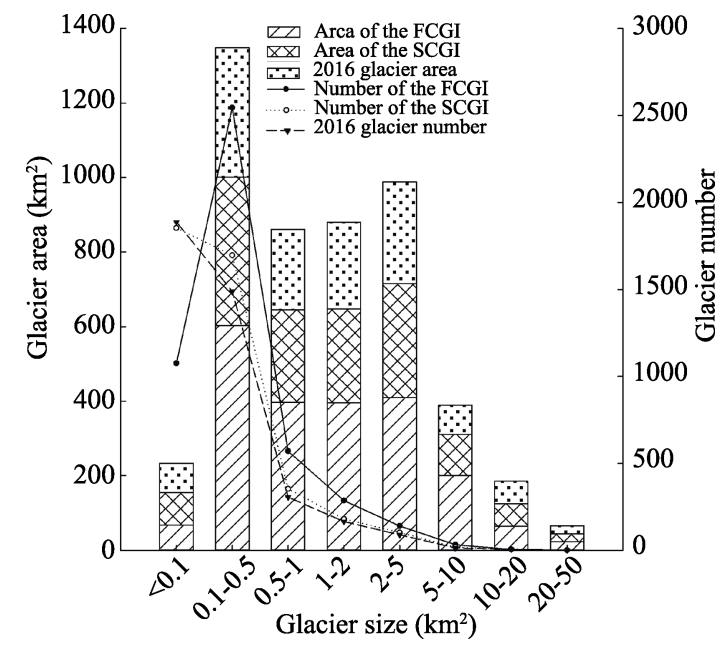

Figure 3 Changes in the number and area of glaciers with different sizes in the Gangdisê Mountains from 1970 to 2016

and an area of $0.5-1 \mathrm{~km}^{2}\left(-1.28 \% \cdot \mathrm{a}^{-1}\right)$. The relative rates of change in glacier area for glaciers with sizes of $1-10 \mathrm{~km}^{2}$ was between $-0.88 \% \cdot \mathrm{a}^{-1}$ and $-0.42 \% \cdot \mathrm{a}^{-1}$, rates of glacier retreat for glaciers with sizes of $10-20 \mathrm{~km}^{2}$ and $>20 \mathrm{~km}^{2}$ were basically equivalent $\left(-0.18 \% \cdot \mathrm{a}^{-1}\right.$ and $-0.20 \% \cdot \mathrm{a}^{-1}$, respectively).

\subsubsection{Changes in glacier altitude}

The main topographical factors affecting the number and size of glaciers were the absolute elevation of the host mountain and the relative elevation above the equilibrium line (Xie and Liu, 2010). The elevation of the glacierized area in the Gangdisê Mountains was analyzed at 100-m intervals (Figure 4), indicating that the glaciers in the Gangdisê Mountains were normally distributed at different altitudes. In the 1970s, the glaciers in the Gangdisê Mountains developed at 5100-7100 m. Glaciers at 5600-6200 m had an area of $1964.17 \mathrm{~km}^{2}$, accounting for $90.90 \%$ of the total glacier area; this altitude interval had the highest concentration of glaciers. The SCGI and 2015-2016 datasets indicated that the glaciers were mainly distributed at $5700-6200 \mathrm{~m}$, with respective areas of $1266.66 \mathrm{~km}^{2}$ and $1120.42 \mathrm{~km}^{2}(85.40 \%$

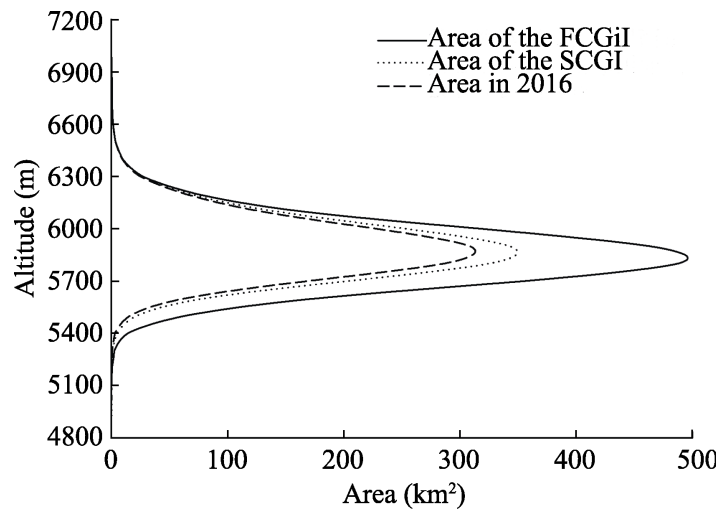

Figure 4 Altitude characteristics of changes in glacier area in the Gangdisê Mountains from 1970 to 2016 and $85.74 \%$ of the corresponding total glaciers, respectively). From 1970 to 2016 , the retreat of glaciers in the Gangdisê Mountains was mainly concentrated in the altitude interval of 5600-6100 m. The reduction in glacier area within this altitude range was $745.48 \mathrm{~km}^{2}$, accounting for $87.29 \%$ of the total glacier retreat. The area of glaciers above $6500 \mathrm{~m}$ remained basically unchanged between 1970 and 2016, and the maximum decrease in glacier area occurred near $5850 \mathrm{~m}$. The middle altitude of glacier area increased from 
5895.2 to $5936.5 \mathrm{~m}$ from 1970 to 2016 .

\subsubsection{Orientation characteristics of glacial changes}

Glacier orientation refers to the direction that a glacier faces, and is usually determined with respect to the eight azimuths: north, northeast, east, southeast, south, southwest, west and northwest (Shi, 2005). As shown in Figure 5, among orientations, the highest number and area of glaciers were oriented north, followed by northeast. Similar numbers of glaciers were oriented northwest and south, although glaciers oriented northwest had a larger area. The number and area of glaciers with all orientations decreased with the exceptions of glaciers oriented south and southeast. Among orientations, the area of north-oriented decreased the most $\left(-431.03 \mathrm{~km}^{2}\right)$ followed by northeast-oriented glaciers $\left(-259.78 \mathrm{~km}^{2}\right)$, while southwest-oriented glaciers exhibited the smallest decrease in area $\left(-24.53 \mathrm{~km}^{2}\right)$. Due to the separation of branch glaciers caused by glacier retreat, the orientations of some glaciers changed, which increased the area of south- and southeast-oriented glaciers by $103.03 \mathrm{~km}^{2}$ and $29.69 \mathrm{~km}^{2}$, respectively. Northwest-oriented glaciers showed the largest percentage decrease in glacier area $(-70.31 \%)$ followed by the north-, south-, northeast-, and southwest-oriented glaciers $(-59.52 \%$ to $-39.84 \%)$. The percentage decrease in glacier area was the smallest for west-oriented glaciers $(-33.53 \%)$.

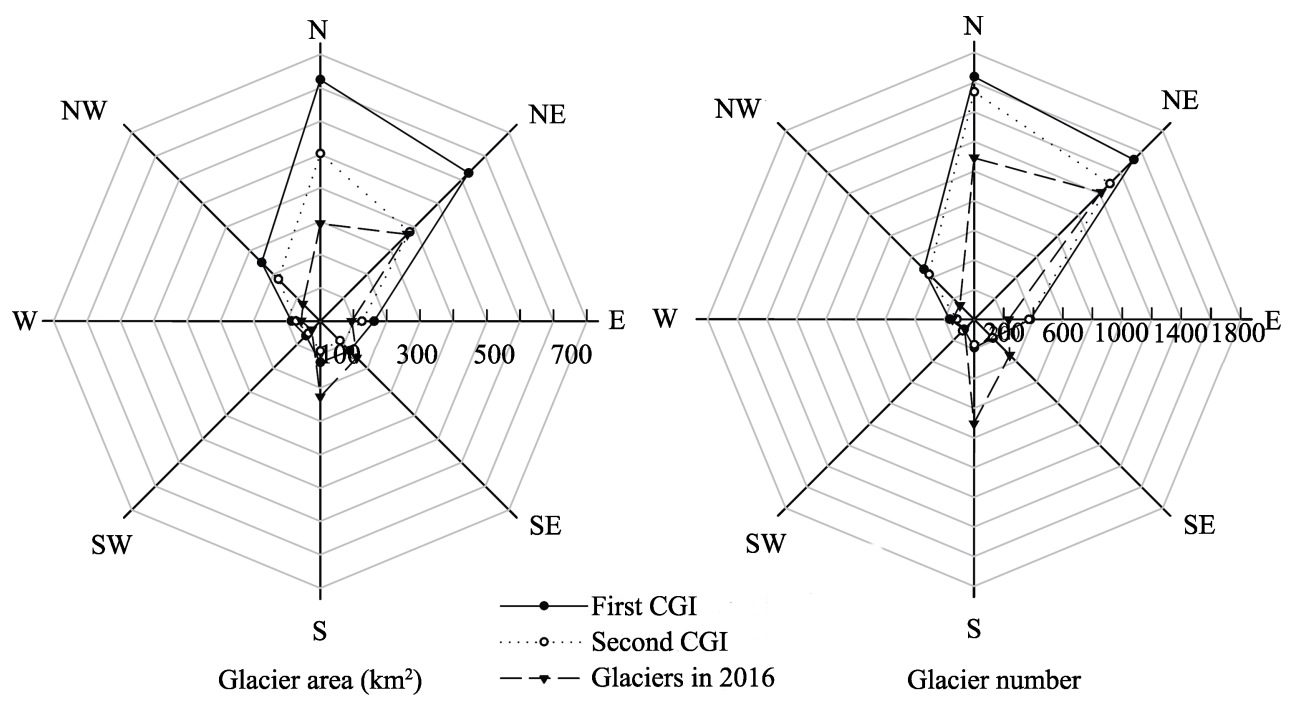

Figure 5 Orientational characteristics of glacial changes in the Gangdisê Mountains from 1970 to 2016

\subsubsection{Regional differences in glacier change}

The Gangdisê Mountains are long and narrow and can be divided into three parts: western (west of the Saga-Coqên Highway), middle (from the Saga-Coqên Highway to the China-Nepal Highway), and eastern (east of the China-Nepal Highway) (Li et al., 1986). To clarify the regional differences in glaciers change in the Gangdisê Mountains, the changes in glacier area from 1970 to 2016 were analyzed at longitudinal intervals of $1^{\circ}$, and the change in area and relative rate of glacier area change in each interval were calculated (Figure 6a). Glacier area decreased in all longitudinal intervals except for one in the western part $\left(79.5^{\circ} \mathrm{E}-80.5^{\circ} \mathrm{E}\right)$. The decrease in glacier area was the largest from $84.5^{\circ} \mathrm{E}-85.5^{\circ} \mathrm{E}(-157.77$ 
$\mathrm{km}^{2}$ ), followed by $82.5^{\circ} \mathrm{E}-83.5^{\circ} \mathrm{E}$, while the decrease was the lowest from $88.5^{\circ} \mathrm{E}-89.5^{\circ} \mathrm{E}$. Based on the relative rates of glacier area change, glacier retreat became faster moving from west to east in the Gangdisê Mountains. The relative rate of glacier change was the highest in the eastern section $\left(-1.72 \% \cdot \mathrm{a}^{-1}\right)$, followed by the middle $\left(-1.67 \% \cdot \mathrm{a}^{-1}\right)$ and western $\left(-0.83 \% \cdot \mathrm{a}^{-1}\right)$. Figure $6 \mathrm{~b}$ shows the distribution of middle altitude of glacier area in different regions of the Gangdisê Mountains from 2015-2016. The middle altitude of glacier area in the Gangdisê Mountains was affected by the terrain and gradually decreased from west to east. Compared to the eastern and middle sections, the western section of the Gangdisê Mountains is higher in altitude, receives less precipitation, and is more affected by the barrier effect of the Himalayas. Thus, the glaciers in this section exhibited less retreat because of the low temperature conditions at high altitude. The eastern section is lower in altitude, receives more precipitation, and has a smaller glacier area, making this section more sensitive to climate change; thus, faster glacial retreat was observed in the eastern section.

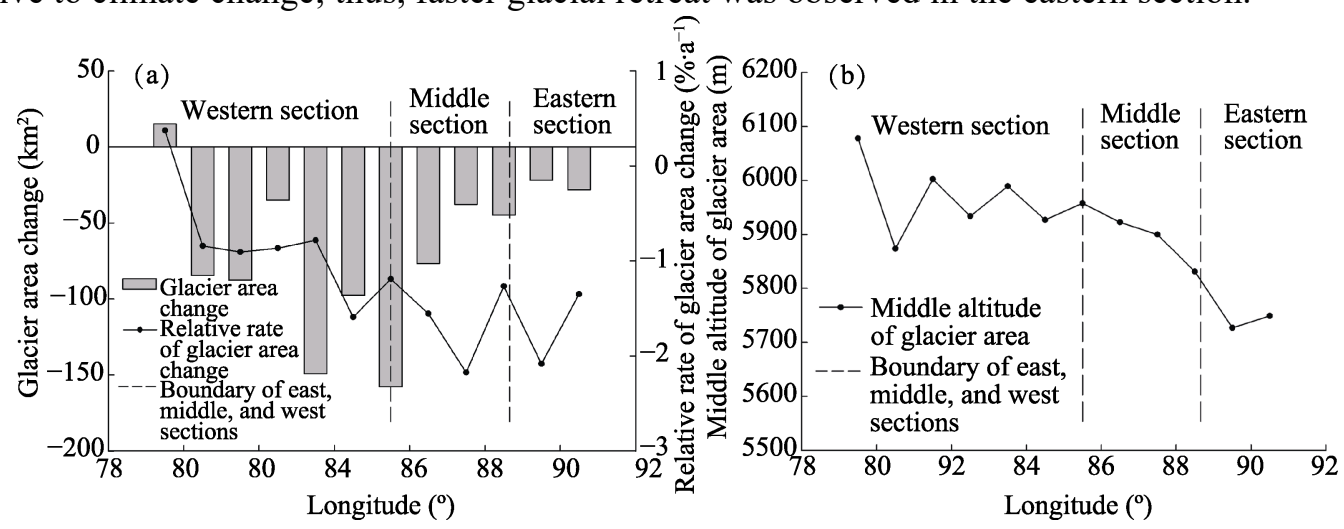

Figure 6 Changes in glacier area in different sections of the Gangdisê Mountains from 1970 to 2016

\section{Discussion}

\subsection{Response of glaciers to climate change}

Precipitation and temperature along with their combination are the main climatic factors affecting glacial development. Precipitation determines the accumulation of glaciers, temperature determines the melting of glaciers, and their combination determines the nature, development, and evolution of glaciers (Xie and Liu, 2010). Temperature has a strong effect on glacial change over long time scales and large distances, whereas precipitation influences glacier advance or retreat over short times and small scales (Gao, 2000). To analyze the responses of glaciers to climate change in the Gangdisê Mountains, the $0.5^{\circ} \times 0.5^{\circ}$ gridded dataset of monthly temperature and precipitation was used to analyze the annual variation in precipitation and temperature of time periods corresponding to glacier ablation (Beedle et al., 2014). As shown in Figure 7, temperature increased during the study period, at a rate of 0.37 ${ }^{\circ} \mathrm{C} / 10 \mathrm{a}$, consistent with the overall trend of increasing temperature in the Tibetan Plateau in recent decades (Liu et al., 2008). Meanwhile, annual precipitation decreased at a rate of 6.74 $\mathrm{mm} / 10 \mathrm{a}$. Temperature usually plays a dominant role in the mass balance of glaciers under the action of climate change (Li et al., 2011). Precipitation must increase by $25 \%$ to com- 
pensate for the mass loss of glaciers caused by a uniform warming of $1{ }^{\circ} \mathrm{C}$ (Oerlemans, 2005). However, in the study area, the glacier mass gain resulting from increased precipitation could not fully compensate the mass loss caused by increasing temperature, resulting in an overall retreat of glaciers in the Gangdisê Mountains. Therefore, the increase in temperature during the ablation period was the most important cause of glacier retreat.

The strong retreat of glaciers in the Gangdisê Mountains was not only affected by regional temperature and precipitation, but also by the average glacier size. The Gangdisê Mountains are characterized by high altitude, steep and broken terrain, and abundant small glaciers. According to the SCGI dataset, the average glacier area in the Gangdisê Mountains is small (Liu et al., 2015). Compared to larger glaciers, small glacier is more sensitive to climate change and retreats faster. In addition, the rapid retreat of glaciers in the Gangdisê Mountains may be related to the emission of black carbon from South Asia (Xu et al., 2009).

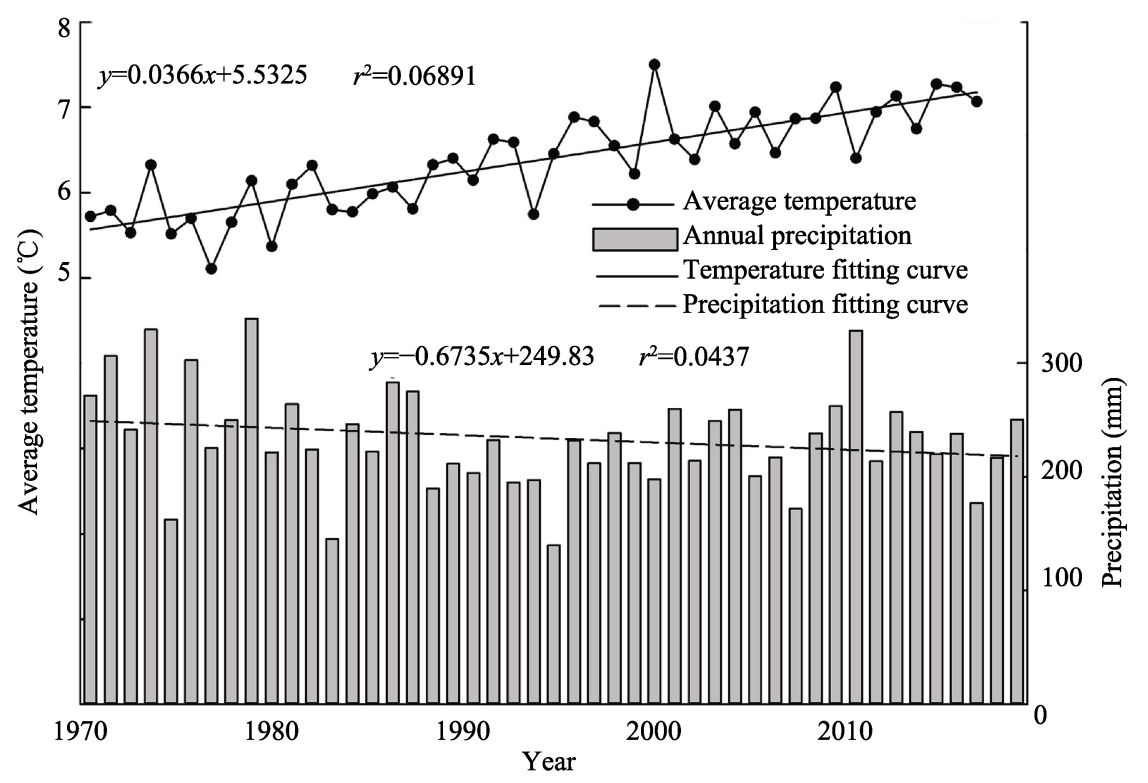

Figure 7 Average temperature during the ablation period and annual precipitation in the Gangdisê Mountains from 1970 to 2016

\subsection{Comparison with glacier changes in typical mountainous areas in western China}

Previous studies have shown that glaciers in western China are generally retreating. Due to differences in the data sources used and study periods considered in different studies along with different glacier resources in different mountain ranges, the rate of change in glacier area (change in glacier area/time interval) cannot truly reflect glacier retreat. To facilitate comparison, we used the method proposed by Sun et al. (2018) to calculate the relative rate of glacier area change and compared the values for different mountains in western China (Table 4). In recent decades, the rate of change in glacier area in the Gangdisê Mountains was lower than in the Tianshan Mountains and Kangri Karpo Mountains. However, in addition to the rate of glacier retreat, these rates are affected to a large extent by the amount of glacier resources in the mountain systems. The relative rate of glacier area change in the Gangdisê Mountains was faster than those of the Himalayas and the Altay Mountains, with 
the highest latitude region of glacier distribution in China. Thus, among all mountain ranges in western China, the Gangdisê Mountains had the fastest rate of glacier retreat.

Table 4 Statistics of glacier changes in western China in recent decades

\begin{tabular}{|c|c|c|c|c|}
\hline Name & $\begin{array}{c}\text { Time } \\
\text { period }\end{array}$ & $\begin{array}{c}\text { Area change } \\
\left(\mathrm{km}^{2}\right)\end{array}$ & $\begin{array}{l}\text { Relative rate of glacier } \\
\text { area change }\left(\% \cdot \mathrm{a}^{-1}\right)\end{array}$ & Data source \\
\hline Altay Mountains & 1960-2009 & -104.61 & -0.94 & Yao et al., 2012 \\
\hline Tianshan Mountains & $1959-2010$ & -1619.82 & -0.40 & Xing et al., 2017 \\
\hline A'Nyêmaqên Mountains & $1966-2000$ & -21.70 & -0.56 & Liu et al., 2002 \\
\hline Altun Mountains & 1973-2010 & -54.22 & -0.46 & Zhu et al., 2013 \\
\hline Qilian Mountains & 1956-2010 & -417.15 & -0.43 & Sun et al., 2018 \\
\hline Middle section of the Tanggula Mountains & 1990-2015 & -115.46 & -1.00 & Wang et al., 2016 \\
\hline Central and Western Qangtang Plateau & $1970-2000$ & -5.07 & -0.03 & Li et al., 2009 \\
\hline Gangdisê Mountains & 1970-2016 & -854.05 & -1.09 & This study \\
\hline Western region of the Nyainqetanglha Range & $1970-2000$ & -52.10 & -0.19 & Shangguan et al., 2008 \\
\hline Kangri Karpo Mountains & $1980-2015$ & -679.50 & -0.82 & Wu et al., 2018 \\
\hline Luozha region, Eastern Himalayas & 1980-2007 & -80.77 & -0.66 & Li et al., 2011 \\
\hline Gongga Mountain & 1974-2010 & -30.20 & -0.35 & Li et al., 2013 \\
\hline
\end{tabular}

\section{Conclusions}

(1) The revised FCGI dataset for the Gangdisê Mountains revealed 4654 glaciers with an area of $2160.50 \mathrm{~km}^{2}$ and an ice volume of approximately $96.06 \mathrm{~km}^{3}$. After supplementing with the SCGI dataset, there were 4207 glaciers with an area of $1483.28 \mathrm{~km}^{2}$ and an ice volume of $66.01 \mathrm{~km}^{3}$. In total, 3953 glaciers with an area of $1306.45 \mathrm{~km}^{2}$ and an ice volume of $58.16 \mathrm{~km}^{3}$ were identified in the Gangdisê Mountains from 2015 to 2016. Among glaciers with different sizes, the glaciers with sizes of $0.1-5 \mathrm{~km}^{2}$ had the largest area, while glaciers with sizes $<0.5 \mathrm{~km}^{2}$ had the largest number.

(2) Among the regions in the Gangdisê Mountains, the Tibetan Plateau interior had the largest number, area, and volume of glaciers, followed by the Ganges River basin and the Indus River basin. Among tertiary basins, the area and number of glaciers were the largest in Dogxung Zangbo basin, while the average area and ice volume were the largest in the Ngangla Ringco basin. The Selin Co basin had the least glacier resources, and the average glacier size was the smallest in the Bangong Co basin.

(3) In the past 50 years, the area of glaciers in the Gangdisê Mountains decreased by $854.05 \mathrm{~km}^{2}(-39.53 \%)$. The decrease in glacier area was mainly concentrated at altitudes of 5600-6100 m, while no change in glacier area was observed at elevations above $6500 \mathrm{~m}$. The middle altitude of glacier area increased from 5895.2 to $5936.5 \mathrm{~m}$ from 1970 to 2016 . Among glacier orientations, north-oriented glaciers suffered the largest area loss $(-431.03$ $\mathrm{km}^{2}$ ), while northwest-oriented glaciers experienced the largest percentage change in glacier area $(-70.31 \%)$. West-oriented glaciers had the smallest loss in area $(-33.53 \%)$.

(4) Compared to other mountains in western China, the Gangdisê Mountains experienced the strongest glacial retreat, and the recession has accelerated in recent years. During the study period, the rate of glacier retreat increased from west to east in the Gangdisê Mountains. The relative rate of glacier change was the highest in the eastern section of the Gang- 
disê Mountains $\left(-1.72 \% \cdot \mathrm{a}^{-1}\right)$, followed by the middle section $\left(-1.67 \% \cdot \mathrm{a}^{-1}\right)$ and the western section $\left(-0.83 \% \cdot \mathrm{a}^{-1}\right)$. Under the background of climate warming, the increased temperature during the ablation period was the most important cause for glacier retreat in the study area.

\section{References}

BeedleM J, Menounos B, Wheate R et al., 2014. Glacier change in the Cariboo Mountains, British Columbia, Canada (1952-2005). Cryosphere, 9(1): 65-80.

Benn D I, Bolch T, Hands K et al., 2012. Response of debris-covered glaciers in the Mount Everest region to recent warming, and implications for outburst flood hazards. Earth-Science Reviews, 114(1): 156-174.

Church J A, White N J, Konikow L F et al., 2013. Revisiting the Earth's sea-level and energy budgets from 1961 to 2008. Geophysical Research Letters, 40(15): 4066-4066.

Gao X Q, 2000. Discussion on the relationship between glacial fluctuation and climate change. Plateau Meteorology, 19(1): 9-16. (in Chinese)

Gardelle J, Berthier E, Arnaud Y, 2012. Slight mass gain of Karakoaram glaciers in the early twenty-first century. Nature Geoscience, 5(5): 322-325.

GardelleJ, Berthier E, Arnaud Y et al., 2013. Region-wide glacier mass balances over the Pamir-Karakoram-Himalaya during 1999-2011. Cryosphere, 9(2): 557-564.

Guo W, Liu S, Xu J et al., 2015. The second Chinese glacier inventory: Data, methods and results. Journal of Glaciology, 61(226): 357-372.

Hall D K, Bayr K J, Schnöer W et al., 2003. Consideration of the errors inherent in mapping historical glacier positions in Austria from ground and space (1893-2001). Remote Sensing of Environment, 86(4): 566-577.

Immerzeel W W, Van Beek L P, Bierkens M F, 2010. Climate change will affect the Asian water towers. Science, 328(5984): 1382-1385.

Kääb A, Treichler D, Nuth C et al., 2015. Brief communication: Contending estimates of 2003-2008 glacier mass balance over the Pamir-Karakoram-Himalaya. Cryosphere, 7(4): 1263-1286.

Kang S C, Chen F, Ye Q H et al., 2007. Glacier retreating dramatically on the Mt. Nyainqentaglha during the last 40 years. Journal of Glaciology and Geocryology, 29(6): 863-873. (in Chinese)

Kargel J S, Leonard G J, Bishop M P et al., 2014. Global Land Ice Measurements from Space. Heidelberg: Springer.

Li D P, Wang L P, Liu S Y et al., 2009. Tupu analysis of the spatio-temporal glacier variations in the central and western Qangtang Plateau since the Little Ice Age. Journal of Glaciology and Geocryology, 31(1): 40-47. (in Chinese)

Li J J, Zheng B X, Yang X J et al., 1986. Tibet Glacier. Beijing: Science Press. (in Chinese)

Li X, Yang T B, Tian H Z et al., 2013. Response of glacier in Gongga Mountain to climate change during the last 40 years. Research of Soil and Water Conservation, 20(6): 125-129. (in Chinese)

Li Z G, Yao T D, Ye Q H et al., 2011. Monitoring glacial variations based on remote sensing in the Luozha region, eastern Himalayas, 1980-2007. Geographical Research, 30(5): 939-953. (in Chinese)

Liu S Y, Ding Y J, Li J et al., 2006. Glaciers in response to recent climate warming in western China. Quaternary Sciences, 26(5): 762-771. (in Chinese)

Liu S Y, Lu A X, Ding Y J et al., 2002. Glacier fluctuations and the inferred climate changes in the A'Nyêmaqên Mountains in the source area of the Yellow River. Journal of Glaciology and Geocryology, 24(6): 701-707. (in Chinese)

Liu S Y, Shangguan D H, Ding Y J et al., 2005. Glacier variations since the early 20th century in the Gangrigabu Range, southeast Tibetan Plateau. Journal of Glaciology and Geocryology, 27(1): 55-63. (in Chinese)

Liu S Y, Yao X J, Guo W Q et al., 2015. The contemporary glaciers in China based on the Second Chinese Glacier Inventory. Journal of Geographical Sciences, 70(1): 3-16. (in Chinese)

Liu W, Guo Q H, Wang Y X, 2008. Temporal-spatial climate change in the last 35 years in Tibet and its 
geo-environmental consequences. Environmental Geology, 54(8): 1747-1754.

Oerlemans J, 1994. Quantifying global warming from the retreat of glaciers. Science, 264(5156): 243 - 244.

Oerlemans J, 2005. Extracting a climate signal from 169 glacier records. Science, 308(5722): 675-677.

$\mathrm{Pu}$ J C, Yao T D, Wang N L et al., 2004. Fluctuations of the glaciers on the Tibetan Plateau during the past century. Journal of Glaciology and Geocryology, 26(5): 517-522. (in Chinese)

Qiu J, 2008. China: The third pole. Nature, 454(7203): 393-396.

Shangguan D H, 2007. Glacier changes in Tarim Interior River Basin using 3S [D]. Lanzhou: Cold and Arid Regions Environmental and Engineering Research Institute, Chinese Academy of Sciences. (in Chinese)

Shangguan D H, Liu S Y, Ding L F et al., 2008. Variation of glaciers in the western Nyainqetanglha range of Tibetan Plateau during 1970-2000. Journal of Glaciology and Geocryology, 30(2): 204-210. (in Chinese)

Shi Y F, 2001. Estimation of the water resources affected by climatic warming and glacier shrinkage before 2050 in west China. Journal of Glaciology and Geocryology, 23(4): 333-341. (in Chinese)

Shi Y F, 2005. A Concise China Glacier Inventory. Shanghai: Shanghai Science Popular Press. (in Chinese)

Shi Y F, Liu S Y, 2000. Pre-estimation for the response of China glaciers to global warming in the 21 st century. Chinese Science Bulletin, 45(4): 434-438. (in Chinese)

Sun M P, Liu S Y, Yao X J et al., 2018. Glacier changes in the Qilian Mountains in the past half century: Based on the revised first and second Chinese glacier inventory. Journal of Geographical Sciences, 28(2): 206-220.

Wang C Q, Yang T B, Ji Q et al., 2016. Remote sensing monitoring of glacier changes in the middle region of Tanggula Mountain. Arid Land Geography, 39(3): 504-512. (in Chinese)

Wang W, Xiang Y, Gao Y et al., 2015. Rapid expansion of glacial lakes caused by climate and glacier retreat in the Central Himalayas. Hydrological Processes, 29(6): 859-874.

Williams R S, Hall D K, Sigurosson O, 1997. Comparison of satellite-derived with ground-based measurements of the fluctuations of the margins of Vatnajökull, Iceland, 1973-92. Annals of Glaciology, 24(3): 72-80.

Wu K P, Liu S Y, Bao W J et al., 2018. Recent glacier mass balance and area changes in the Kangri Karpo Mountains from DEMs and glacier inventories. Cryosphere, 12(1): 103-121.

Xie Z C, Liu C H, 2010. Introduction to Glaciology. Shanghai: Shanghai Science Popular Press. (in Chinese)

Xing W C, Li Z Q, Zhang H et al., 2017. Spatial-temporal variation of glacier resources in Tien Shan Mountains since. Journal of Geographical Sciences, 72(9): 1594-1605. (in Chinese)

Xu B Q, Cao J J, Hansen J et al., 2009. Black soot and the survival of Tibetan glaciers. Proceedings of the National Academy of Sciences. 106(52): 22114-22118.

Xu Q, Ding L, 2015. Paleoelevation research on Gangdisê Mountains and Tibetan Plateau. China Science Foundation, (1): 54 - 59. (in Chinese)

Yao X J, Liu S Y, Guo W Q et al., 2012. Glacier change of Altay Mountain in China from 1960 to 2009: Based on the Second Glacier Inventory of China. Journal of Natural Resources, 27(10): 1734-1745. (in Chinese)

Yao T, Thompson L, Yang W et al., 2012. Different glacier status with atmospheric circulations in Tibetan Plateau and surroundings. Nature Climate Change, 2(9): 663-667.

Ye Q H, Chen F, Yao T D et al., 2007.Tupu of glacier variations in the Mt. Naimonanyi region, western Himalayas, in the last three decades. Journal of Remote Sensing, 11(4): 511-520. (in Chinese)

You L Y, Yang J C, 2013. Geomorphology in China. Beijing: Science Press. (in Chinese)

Zhang J T, He X J, Shangguan D H et al., 2012. Impact of intensive glacier ablation on arid regions of northwest China and its countermeasure. Journal of Glaciology and Geocryology, 34(4): 848-854. (in Chinese)

Zhu H Y, Yang T B, Tian H Z et al., 2013. Glacier variation in the Altun Mountains from 1973 to 2010. Geographical Research, 32(8): 1430-1438. (in Chinese) 